\title{
Sensory analysis of a noodle prepared with carrot flour by overweight children
}

\begin{abstract}
The objective of this work was to use the carrot flour to develop new noodles formulations, and to evaluate their sensory acceptance by overweight children. The acceptance of noodles was evaluated using 5-point facial and verbal hedonic scales for boys $(n=12)$ and girls $(n=13)$. It was observed that the acceptance of the formulation A (control) was statistically different from that formulation C, which had $50 \%$ of carrot flour, while the formulation B ( $25 \%$ of carrot flour) did not differ statistically from other formulations. There was not statistical difference according to the amount of noodle consumed to gender. The formulations $\mathrm{B}$ and $\mathrm{C}$ showed higher concentration of fibers than formulation A, however the amount of proteins was higher in formulation A. The concentration of lipids did not differ statistically between the developed formulations, while the amount of ashes was higher in the formulation $\mathrm{C}$. The noodle formulations with carrot flour (B and C) were equally accepted in both assessments (facial and verbal), suggesting that they may be a viable option for the development of a new product with high fiber content.
\end{abstract}

Keywords: daucus carota, functional foods, carotenoids, fibers
Volume 7 Issue I - 2017

\author{
Martha Elisa Ferreira de Almeida,' Andressa \\ Cristina de Melo, ${ }^{2}$ Henrique Silvano Arruda, ${ }^{3}$ \\ Taciana Lunelli, ${ }^{4}$ Richtier Gonçalves da \\ Cruz, ${ }^{4}$ Diego Alvarenga Botrel, ${ }^{5}$ Regiane \\ Victória de Barros Fernandes ${ }^{5}$ \\ 'Institute of Biological Sciences and Health, Federal University of \\ Viçosa (UFV/CRP), Brazil \\ ${ }^{2}$ Institute of Agricultural Sciences, Federal University of Viçosa \\ (UFV/CRP), Brazil \\ ${ }^{3}$ Food Science Department, University of Campinas \\ (UNICAMP), Brazil \\ ${ }^{4}$ Food Science and Technology Department, College of \\ Agriculture "Luiz de Queiroz"' - São Paulo University, Brazil \\ ${ }^{5}$ Food Science Department, Federal University of Lavras (UFLA), \\ Brazil
}

\author{
Correspondence: Martha Elisa Ferreira de Almeida, \\ Institute of Biological Sciences and Health, Federal University \\ of Viçosa (UFV/CRP), Rio Paranaíba Campus, Post Office: \\ 22, Rio Paranaíba, MG, Brazil, Zip Code: 38810-000,Tel + \\ 553438559300,Email martha.almeida@ufv.br
}

Received: May 10, 2017| Published: July 03, 2017

\section{Introduction}

In Brazil and other countries the prevalence of chronic noncommunicable diseases has increased as a result of inadequate nutrition. Besides that, obesity epidemic spreads rapidly over the world. Thus, for the control of these diseases, strategies are being defined, which ones, has used the prevention and treatment to the promotion of the healthy eating. ${ }^{1}$

Childhood obesity is a problematic condition for the person, since it may be associated with diabetes mellitus, hypertension and dyslipidemia. The increased consumption of hypercaloric foods and lack of physical activity, related to the use of many hours of television, video games and computer are the main factors associated with overweight. The overweight in this life stage increases the chances of the individual to remain obese throughout their life, thus, it is necessary to change these eating habits, since at that stage the nutritional intervention has been showed the best results. ${ }^{2}$ For the treatment of obesity several strategies can be adopted, based on behavioral therapies directed to the modification of activities and habits related to nutrition, physical exercise to increase caloric expenditure, drugs and surgeries, as well as nutrition guidelines to reduce consumption calories with an approach in the use of healthy foods. ${ }^{3}$

Noodle is a traditional food on meals, putting Brazil in third place in the world market in the consumption of this food, behind only Italy and the United States of America. Besides that, noodles are acquiring popularity in the world because of several advantages including convenience, longer shelf-life, and inexpensive price. ${ }^{4}$ So that, it shows the socioeconomic importance of this food, as well as being a source of nutrients, it generates jobs and income for the population.
In Brazil, one of the most commonly consumed vegetables is the carrot (Daucus carota L.), which is a food rich in alpha-carotenoids (precursor molecule of vitamin A), and it is used as a dye in noodles. In the last years, the consumption of carrot and its derived products has increased based on their higher concentration of carotene compared to other foods ${ }^{5,6}$ Carrot is also an important source of magnesium, vitamin $\mathrm{K}$ and dietary fiber, as many other important nutrients. ${ }^{7}$ The food industry generates many millions of tons per year of processed plant by-products ${ }^{8}$ and the carrot can be consumed grated, diced, sliced, in sticks, juices and cakes.

An increased consumption of healthy foods to reduce chronic diseases risks is needed. ${ }^{9}$ In this case, the development of noodles in which there is partial replacement of wheat flour by carrot tends to add value and assigning nutritional characteristics to this, providing the use of carrots that are wasted in the countryside; beyond it stimulates the consumption of this vegetable by children which ones generally have low consumption. Therefore, the noodles with carrot flour can improve the nutritional status of overweight children that often use this as one of the basic items in the meals served in kindergartens and schools. The aim of this study was to use carrot flour in development of noodles, and evaluate their sensory acceptance by overweight children.

\section{Materials and methods}

The study was conducted with overweight children after their caregivers had been signed the Free Consent and Enlightened Informed, and the children had been signed the Free Assent and Enlightened Informed as well as the approval of this project by the Ethics Committee on Research with beings human of Viçosa Federal 
University, protocol number 478.951. The raw material (carrot) after has been acquired in the local market of Rio Paranaíba (MG) was transported to the Dietetics and Nutrition Laboratory at the Federal University of Viçosa, Rio Paranaíba Campus. The carrot has been prewashed in running water and sanitized with $150 \mathrm{ppm}$ solution of free residual chlorine for $10 \mathrm{~min}$. After removal of husks with stainless steel knife, the carrots were grated in a domestic grate device, spread on trays and placed in an oven with air circulation at $70^{\circ} \mathrm{C}$ for six hours. The material was blended in a domestic device, sieved and stored at room temperature in closed jars until the preparation of the noodles.

Eggs, unleavened wheat flour and carrot used in noodles elaboration were obtained in the local market of Rio Paranaíba (MG). Three noodle formulations were prepared: formulation A (control), formulation B ( $25 \%$ of carrot flour), formulation C $(50 \%$ of carrot flour) through the following steps: mixing the ingredients; homogenization; kneading, molding and drying. The description of the ingredients and their amounts used in the formulation of each noodle are shown in Table 1. Protein concentrations, dietary fiber, ashes and lipids in noodles were determined by AOAC. ${ }^{10}$

The noodles were prepared following the homemade fresh noodles pattern. The flours were placed on a marble countertop with a hole in the center, where eggs were broken and mixed. The mixture was kneaded for five minutes until becomes smooth and soft. An amount of wheat flour was used to sprinkle the batter, avoiding it be stucked to the countertop. When the batter became soft and homogeneous, it was cut into pieces that have been opened with noodles preparation machine, cutting it in noodles format. Each kilogram of prepared noodle has been cooked for 20 minutes in two liters of water containing $15 \mathrm{~mL}$ of soybean oil and $18 \mathrm{~g}$ salt. ${ }^{11}$ In preparation of the sauce were used two large onions, two cloves of garlic, six tablespoons of olive oil, $350 \mathrm{~g}$ of Italian dressing (tomato paste/sauce), $1.2 \mathrm{~kg}$ of minced meat, four cups of filtered water and two level tablespoons of sugar. Each sample of noodles and its sauce, with approximately $65 \mathrm{~g}$, was served in a monadic way, coded with three-digit numbers, and accompanied by a glass of mineral water at room temperature for its use among the samples tasting.

Table I Formulations used to prepare the noodles

\begin{tabular}{llll} 
Ingredients & Formulation A & Formulation B & Formulation C \\
\hline Egg (unit) & $\mathrm{I}$ & $\mathrm{I}$ & $\mathrm{I}$ \\
Wheat flour (g) & 100 & 75 & 50 \\
Carrot flour (g) & - & 25 & 50 \\
\hline
\end{tabular}

The sensory evaluation of noodle formulations has been done before the school meals consumption, to avoid interference in the results. Each child evaluated all noodle formulations. To evaluate the acceptance of the noodles were used 5-point facial (Figure 1) and verbal hedonic scales for boys and girls as described by Silva et al. ${ }^{12}$ The facial scale was completed by the child, while the verbal scale was made after asking the opinion about the ingested food.

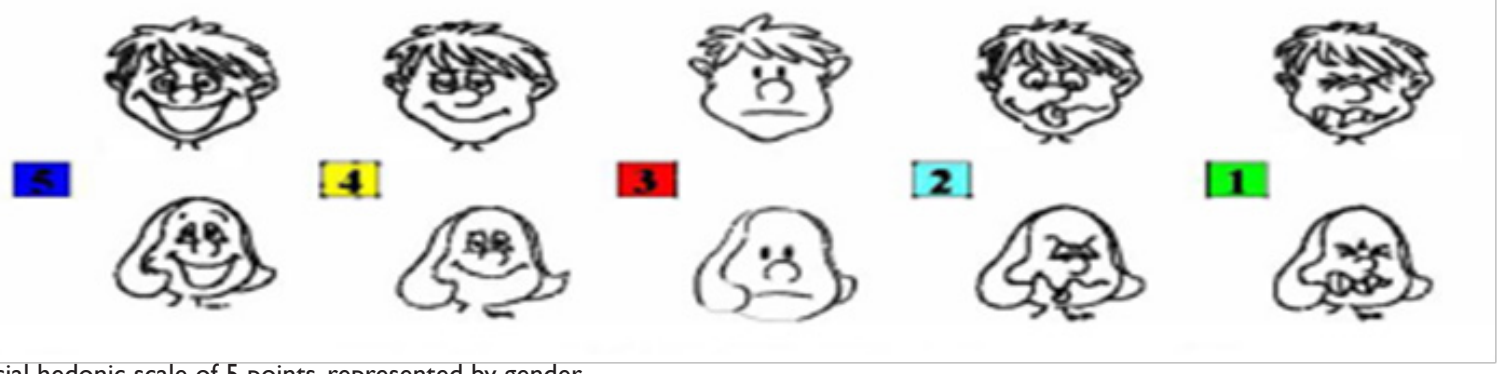

Figure I Facial hedonic scale of 5 points, represented by gender.

Definition of scale values: 5 - I loved it, 4 - I liked it, 3 - indifferent, 2 - I didn't it, I - I hated it.

The Acceptability Index was calculated using the expression:

$\mathrm{AI}=($ score achieved by the product $\mathrm{X} 100)$ /maximum score that could be attributed to the product. ${ }^{13}$

The amount of noodle was weighed before and after the sensory analysis. Thus, the consumption of each noodle formulation was obtained by the difference between the amount offered and the leftover of it. To evaluate the knowledge and the intake noodles and carrots, a semi-structured questionnaire was used.

The results of facial and verbal analysis were evaluated by Analysis of Variance (ANOVA), followed by the Tukey's test in case of a significant difference. Both tests were done at $5 \%$ probability.

\section{Results and discussion}

The analysis of the proximate composition for the different formulations of noodles is presented in Table 2. As it can be seen, there was no significant difference $(\mathrm{p}>0.05)$ between the amount of lipids in the different formulations, however the formulation $\mathrm{C}$ showed higher concentrations of ashes and dietary fiber than the others, while the formulation $\mathrm{B}$ had a higher concentration of dietary fiber that the formulation $\mathrm{A}$. On the other hand the concentration of proteins was higher in the formulation A (without flour carrot).

Table 2 Means and standard deviation of chemical composition of different noodle formulations expressed on a dry basis

\begin{tabular}{lllll}
\hline Noodle & Lipids & Proteins & Ashes & Dietary fiber \\
\hline Formulation A & $4.23 \pm 0.02^{\mathrm{a}}$ & $17.09 \pm 0.09^{\mathrm{a}}$ & $2.01 \pm 0.02^{\mathrm{b}}$ & $2.58 \pm 0.07^{\mathrm{c}}$ \\
Formulation B & $4.66 \pm 0.09^{\mathrm{a}}$ & $15.85 \pm 0.08^{\mathrm{b}}$ & $2.21 \pm 0.0 \mathrm{I}^{\mathrm{b}}$ & $10.09 \pm 0.09^{\mathrm{b}}$ \\
Formulation C & $4.65 \pm 0.05^{\mathrm{a}}$ & $14.97 \pm 0.09^{\mathrm{b}}$ & $3.7 \mathrm{I} \pm 0.06^{\mathrm{a}}$ & $17.54 \pm 0.05^{\mathrm{a}}$ \\
\hline
\end{tabular}

Formulation A (Control); Formulation B ( $25 \%$ of carrot flour) and Formulation C ( $50 \%$ of carrot flour).

Means and standard deviations followed by the same letter did not significantly differ ( $p>0.05)$ by Tukey's test from each other in the same column, for each variable. 
The results of proximate composition are similar only in amount of ashes with the work of Choo \& Aziz, ${ }^{14}$ wherein the authors evaluated the composition of noodles with $30 \%$ of banana flour and $\beta$-glucan, however the concentration of proteins, lipids and mainly of fibers was higher, since that the maximum concentration of fibers found by the authors was $5.91 \%$, and in this study the formulations B and C showing an amount of 10.09 and $17.54 \%$, respectively. In addition, it was observed that the amount of fibers and ashes increased with the increase of concentration carrot flour. Thus, these samples can be source of these important nutrients that are related with the decrease of risk of many health problems like diabetes mellitus and heart disease, and the obesity presents itself as a risk factor for the development of these.

The study included 13 girls and 12 boys with 6-9years, overweight, students of the Municipal School Presidente Tancredo . Neves, in Rio Paranaíba, Minas Gerais, Brazil. There was no difference ( $p>0.05)$ between the formulations using the facial scale for both genders, however, when assessing the verbal scale was observed that girls accepted least the formulation C (50\% of carrot flour) compared with the control formulation (A). Among genders, girls attributed higher scores to all noodle formulations in both scales. When evaluating the general scores of the noodle formulations through the facial or verbal scales, it was observed that the control formulation (A) statistically differed and was higher than the formulation $\mathrm{C}$, which had $50 \%$ of carrot flour. Though, the formulation B (25\% of carrot flour) was not significantly different of the others formulations (Table 3), highlighting that the two formulations with carrot flour were equally accepted.

Table 3 Means and standard deviation of attributed notes, according to gender, about the acceptance of the noodles formulations using the facial and verbal scales

\begin{tabular}{lllllll}
\hline Gender & Facial scale & \multicolumn{5}{c}{ Verbal Scale } \\
\hline & Formulation A & Formulation B & Formulation C & Formulation A & Formulation B & Formulation C \\
\hline Female $(n=13)$ & $4.77 \pm 0.44^{\mathrm{ns}}$ & $4.54 \pm 0.66^{\mathrm{ns}}$ & $4.08 \pm 1.19^{\mathrm{ns}}$ & $4.77 \pm 0.44^{\mathrm{a}}$ & $4.38 \pm 0.65^{\mathrm{ab}}$ & $3.92 \pm 1.19^{\mathrm{b}}$ \\
Male $(\mathrm{n}=12)$ & $4.58 \pm 0.67^{\mathrm{ns}}$ & $3.92 \pm 1.16^{\mathrm{ns}}$ & $3.67 \pm 1.44^{\mathrm{ns}}$ & $4.33 \pm 0.65^{\mathrm{ns}}$ & $3.75 \pm 1.29^{\mathrm{ns}}$ & $3.42 \pm 1.44^{\mathrm{ns}}$ \\
General $(\mathrm{n}=25)$ & $4.68 \pm 0.56^{\mathrm{ab}}$ & $4.24 \pm 0.97^{\mathrm{ab}}$ & $3.88 \pm 1.30^{\mathrm{b}}$ & $4.56 \pm 0.58^{\mathrm{a}}$ & $4.08 \pm 1.04^{\mathrm{ab}}$ & $3.68 \pm 1.31^{\mathrm{b}}$ \\
\hline
\end{tabular}

Formulation A (Control); Formulation B ( $25 \%$ of carrot flour) and Formulation C ( $50 \%$ of carrot flour). ns = not significant to ANOVA. Different letters on the line, on the same scale, shows statistical differences at $5 \%$ significance by Tukey's test.

The formulations of noodles with carrot flour got positive scores of acceptance in both scales (facial and verbal), since the means score was higher than 2.5 points and represented $50 \%$ of the scale value, suggesting that they represent options for new products that can be launched in the market. Among the noodles with carrot flour, the girls attributed means scores to the formulation B (25\% of carrot flour) in both scales. The quantities of noodles consumed in different formulations did not differ statistically $(\mathrm{p}>0.05)$ for both genders and in general way (Table 4). The means reported for the formulation $\mathrm{C}$ (50\% of carrot flour) was the lowest value and it has presented the most distinct values (minimum and maximum), in other words, this one was the most appreciated by some children and also the most rejected by others.

Table 4 Means and standard deviation of the consumed amount and Acceptability Index of noodle formulations for children

\begin{tabular}{|c|c|c|c|c|c|c|c|}
\hline \multirow[b]{2}{*}{ Gender } & \multirow{2}{*}{$\begin{array}{l}\text { Noodle } \\
\text { Formulation }\end{array}$} & \multicolumn{3}{|c|}{ Consumed amount (\%) } & \multicolumn{3}{|l|}{ Acceptability index } \\
\hline & & $\begin{array}{l}\text { Means and standard } \\
\text { deviation }\end{array}$ & $\begin{array}{l}\text { Minimum } \\
\text { value }\end{array}$ & $\begin{array}{l}\text { Maximum } \\
\text { value }\end{array}$ & $\begin{array}{l}\text { Means and standard } \\
\text { deviation }\end{array}$ & $\begin{array}{l}\text { Minimum } \\
\text { value }\end{array}$ & $\begin{array}{l}\text { Maximum } \\
\text { value }\end{array}$ \\
\hline \multirow{3}{*}{ Female } & A & $42.25 \pm 35.56^{\mathrm{ns}}$ & 12.78 & 96.95 & $95.38 \pm 8.77^{\mathrm{ns}}$ & 80 & 100 \\
\hline & B & $53.25 \pm 39.39^{\text {ns }}$ & 11.09 & 97.9 & $89.23 \pm 13.20^{\mathrm{ns}}$ & 60 & 100 \\
\hline & $\mathrm{C}$ & $35.32 \pm 34.22^{\mathrm{ns}}$ & 6.69 & 94.59 & $81.54 \pm 23.75^{\mathrm{ns}}$ & 40 & 100 \\
\hline \multirow{3}{*}{ Male } & $A$ & $55.13 \pm 26.55^{\mathrm{ns}}$ & 11.76 & 94.62 & $91.67 \pm 13.37^{\mathrm{ns}}$ & 60 & 100 \\
\hline & B & $47.59 \pm 32.38^{\mathrm{ns}}$ & 7.81 & 96.22 & $78.33 \pm 23.29^{\mathrm{ns}}$ & 40 & 100 \\
\hline & $\mathrm{C}$ & $43.91 \pm 32.92^{\mathrm{ns}}$ & 5.12 & 99.1 & $73.33 \pm 28.7 I^{\mathrm{ns}}$ & 20 & 100 \\
\hline \multirow{3}{*}{ General } & A & $48.43 \pm 31.60^{\mathrm{ns}}$ & 11.76 & 96.95 & $93.60 \pm 11.14^{\mathrm{a}}$ & 60 & 100 \\
\hline & B & $50.54 \pm 35.56^{\mathrm{ns}}$ & 7.81 & 97.9 & $84.00 \pm 19.15^{\mathrm{ab}}$ & 40 & 100 \\
\hline & $\mathrm{C}$ & $39.45 \pm 33.19^{\text {ns }}$ & 5.12 & 99.1 & $77.60 \pm 26.03^{b}$ & 20 & 100 \\
\hline
\end{tabular}

Formulation A (Control); Formulation B ( $25 \%$ of carrot flour); Formulation C ( $50 \%$ of carrot flour). ns = not significant to ANOVA. Different letters on the column, on the same scale, shows statistical differences at $5 \%$ significance by Tukey's test.

There was no difference $(\mathrm{p}>0.05)$ related to the Acceptability Index on the three noodle formulations between genders and in general (Table 4). Upon the Acceptability Index higher than $70 \%{ }^{13}$ all formulations were accepted. However, it is suggested that other noodle formulations with lower amounts of carrot flour should be prepared so that they can be used in school meals, since the formulations of this study $(50 \%$ of carrot flour for girls and 25 and $50 \%$ of carrot flour for boys) were not accepted according to the test parameter of acceptance 
of the Law of the National Fund for Education Development, number 32 of August 10th, 2006, which states that a food must have minimum acceptance of $85 \%$ to be inserted into the menu of school meals. ${ }^{15}$

Casagrandi et al., ${ }^{16}$ when assessing the replacement of wheat flour by the gandu beans in amounts of 5, 10 and 15\% reported that the means scores suffered a gradual decrease with the increase of the amount of flour. In amounts of 5 to $10 \%$ there was no statistical difference from the formulation control, however the formulation with $15 \%$ had a lower acceptance that the control noodle $(p<0.05)$, as observed in this study for formulation with $50 \%$ of carrot flour which showed a lower acceptance that the formulation A (control). On the other hand, Rocha et al., ${ }^{11}$ evaluating noodles added with ora-pronobis flour to $1,1.5$ and $2 \%$ noted that the formulation containing $1 \%$ ora-pro-nobis flour was the least accepted and that the others (1.5 and $2 \%$ ) did not differ statistically.

When asked about the number of times that they habitually feed daily, it was observed that the girls were on means 3.46 meals and boys consumed the amount of 2.75 . Given the context of the nutritional transition and chronic diseases, the Ministry of Health developed the 10 Steps to Healthy Eating ${ }^{17}$ of which step 1 stands out - "Have at least three meals and a snack a day. Do not skip meals". However, in this study it was noted that some children, especially boys, did not have the number of meals recommended by the Ministry of Health, which may be contributing to overweight, since all of them had such a pathological condition.

Vinholes et al. ${ }^{18}$ observed that among adults evaluated in in Pelotas, RS, Brazil only $57.10 \%$ of the individuals performed three meals and one snack per day. Redondo et al., ${ }^{19}$ identified in the elderly population that the greatest number of daily meals was associated with lower concentrations of total cholesterol, VLDL-cholesterol, serum triglycerides and lower energy consumption.

The daily consumption of noodle was mentioned by only $16.66 \%$ of the boys, who reported as a justification "because I like it" and "because it brings good nutrients". The mean consumption of this food was 1.78 times a week for boys and 1.38 for girls. Nicoletti et al., ${ }^{20}$ pointed out that there are indications that the increased and regular consumption of noodles, compared to the combination of rice and beans, would be the main factor for the increased incidence of obesity at all stages of life, especially among populations which have a lower economic status.

Toloni et al., ${ }^{21}$ studying children in public and philanthropic nurseries and kindergartens of São Paulo (Brazil) found that about 2/3 of them had received before 12 months of age, obesogenic foods as instant noodles, snacks, filled biscuits, candies, lollipops, chocolate, sausages and artificial juices. It was observed that low maternal education doubled the risk of early introduction of instant noodles and snacks and among mothers under the age of 20years, the risk of early introduction of instant noodles was 7.5 times higher. Bueno et al., ${ }^{22}$ point out that the lifestyle adopted by the current society has introduced early in children's diets atherogenic and obesogenic foods such as noodles, which are mistakenly consumed in exaggeration by adults. Jahns et al. ${ }^{23}$ highlighted that the continuous and in excess intake of obesogenic foods can set the chronic course and poor eating habits and may remain at all stages of life, contributing to the obesity and chronic noncommunicable diseases.

Daily consumption of a food by adults is one of the possible markers of children's food intake and consequently of their nutritional status, as parents directly influence the food intake of children, healthy eating habits should be practiced from childhood to prevent non-communicable chronic diseases. In addition, depending on the availability of food, preferences are learned and can promote or inhibit consumption of healthy eating. ${ }^{24}$ Since the 1980 has been observed a reduction in the consumption of rice and an increase in the consumption of noodles. This fact is suggested to be due on the inclusion of women in the outside labor market and lower supply of domestic labor market for food preparation, which has led the housewife to opt for rapid preparation of dishes. ${ }^{25}$ Denardin et al., ${ }^{25}$ observed mice fed with noodles had higher levels of total cholesterol, triglycerides and lower HDL-cholesterol compared to animals which have received a rice diet, and this fact can directly influence the progression of cardiovascular disease and diabetes mellitus type 2 .

The daily consumption of carrots was reported by $16.67 \%$ of boys and $16.67 \%$ girls. The boys who have said they did not consume carrot daily reported that they use to eat 0.77 times a week, while the girls related to ingest 1.27 times a week. Several children reported that noodle is important to grow, and all children assessed have stated that the carrot is important for their growth. The carrot is an important source of pro-vitamin A, which is needed at all stages of growth mainly of preschool children because it acts in the processes of differentiation and maintenance of epithelial integrity and vision. ${ }^{26}$ When asked if they thought that their mother had more weight than she should have, $69.23 \%$ of girls and $16.70 \%$ of boys answered affirmatively. Locard et al., ${ }^{27}$ reported that parents are critical in the formation of eating habits, and to the prevention and treatment of childhood overweight, emphasizing also that the chance of a child becoming overweight is higher in families of obese parents, who often have lifestyles considered unhealthy by eating foods favorable to this condition and sedentary lifestyle.

Francis \& Birch $^{28}$ found that overweight mothers' restrictive feeding practices when daughters were age 5years predicted daughters' eating in the absence of hunger over time, and higher eating in the absence of hunger scores were associated with greater Body Mass Index, highlighting that maternal nutritional status and the food restriction imposed is a risk factor for the increase in the child's body weight. When asked about the consumption of noodles made with carrots, $91.67 \%$ of boys and $76.92 \%$ of girls said they would do their intake, since that they reported that both noodles as carrots are important for health.

\section{Conclusion}

All noodles formulations with carrots showed positive scores of acceptance in both facial and verbal scales, being the means scores were higher than the 2.5 points $(50 \%$ of the 5 -point scale). There was no statistical difference between the noodle amounts consumed in different formulations for both genders. In relation to the means amount eaten, the formulation $\mathrm{C}$ showed the greatest discrepancy in the analysis of children, in other words, this one was the most appreciated for some children (highest maximum value) and the most rejected by others (lower minimum value). The children said they would eat a noodle made with carrot, leaving thus a possibility for future studies with smaller amounts of carrot flour to be tested according to National Fund for Education Development legislation of 2006 , and in case of acceptance, be prepared for this target group in kindergartens, schools and their homes. The proximate composition showed that the developed noodles with the addition of carrot flour can be an important source of nutrients with highlighted for fiber. The use of carrots as a partial substitute of wheat flour in dough noodles was feasible, since it improves the sensory quality of the product and 
may also contribute to the reduction of environmental pollution and waste in the countryside and the retail establishments.

\section{Acknowledgements}

There were no funding sources for the study.

\section{Conflicts of interest}

The author declares no conflict of interest.

\section{References}

1. Erlanson Albertsson C, Albertsson PA. The use of green leaf membranes to promote appetite control, suppress hedonic hunger and loose body weight. Plant Foods Hum Nutr. 2015;70(3):281-290.

2. Filgueiras MC, Lima NVR, Souza SS, et al. Prevalência de obesidade em crianças de escolas públicas. Rev Ciência \& Saúde. 2012;5(1):41-47.

3. Mancini MC, Halpern A. Pharmacological treatment of obesity. Arq Bras Endocrinol Metab. 2002;46(5):497-513.

4. Jang A, Kim JY, Lee S. Rheological, thermal conductivity, and microscopic studies on porous structured noodles for shortened cooking time. LWT - Food Science and Technology. 2016;74:143-747.

5. Chen ZG, Guo XY, Wu T. A novel dehydration technique for carrot slices implementing ultrasound and vacuum drying methods. Ultrason Sonochem. 2016;30:28-34.

6. Wu B, Pan Z, Qu W, et al. Effect of simultaneous infrared dry-blanching and dehydration on quality characteristics of carrot slices. $L W T-$ Food Science and Technology. 2014;57(1):90-98.

7. Nowacka M, Wedzik M. Effect of ultrasound treatment on microstructure, colour and carotenoid content in fresh and dried carrot tissue. Applied Acoustics. 2016;103(B):163-171.

8. Mildner-Szkudlarz S, Bajerska J, Górnaś P, et al. Physical and bioactive properties of muffins enriched with raspberry and cranberry pomace powder:a promising application of fruit by-products rich in biocompounds. Plant Foods Hum Nutr. 2016;71(2):165-173.

9. Islas Rubio AR, de la Barca AM, Molina-Jacott LE, et al. Development and evaluation of a nutritionally enhanced multigrain tortilla snack. Plant Foods Hum Nutr. 2014;69(2):128-133.

10. Association of Official Analytical Chemists. Official methods of analysis of AOAC International. 17th ed. Washington DC, USA; 2000.

11. Rocha DRC, Pereira Júnior GA, Vieira G, et al. Noodles added of ora-pro-nobis (Pereskia aculeata Miller) dehydrated. Alim Nutr. 2008;19(4):459-465.

12. Pinto e Silva MEM, Coelho HDS, Veiga A. Using hedonic facial scale for testing the acceptance of soy milk preparations by children from 2 to 6 years old. Eur J Clin Nutr. 2000;54:S13.

13. Castro LIA, Vila Real CM, Pires ISC, et al. Quinoa (Chenopodium quinoa Willd):in vitro digestibility, development and sensorial analysis of preparations for celiac patients. Alim Nutr. 2007;18(3):413-419.
14. Choo CL, Aziz NAA. Effects of banana flour and $\beta$-glucan on the nutritional and sensory evaluation of noodles. Food Chem. 2010;119(1):34-40.

15. Brasil. Estabelece normas para a execução do Programa Nacional de Alimentação Escolar - PNAE. Brasília: Diário Oficial da União, Poder Executivo, , DF, 24 ago. Seção 1; 2006. 27 p.

16. Casagrandi DA, Canniatti-Brazaca SG, Salgado JM, et al. Technological, nutritional and sensorial analysis of macaroni elaborated with wheat and pigeon pea flours. Rev Nutr. 1999;12(2):137-143.

17. Brasil Ministério da Saúde. Secretaria de Atenção à Saúde, Departamento de Atenção Básica. 2nd ed. Brasil: Guia alimentar para a população brasileira; 2014. $156 \mathrm{p}$.

18. Vinholes DB, Assunção MCF, Neutzling MB. Frequency of healthy eating habits measured by the 10 Steps to Healthy Eating score proposed by the Ministry of Health. Pelotas, Rio Grande do Sul State, Brazil. Cad Saúde Pública. 2009;25(4):791-799.

19. Redondo MR, Ortega RM, Zamora MJ, et al. Influence of the number of meals taken per day on cardiovascular risk factors and the energy and nutrient intakes of a group of elderly people. Int J Vitam Nutr Res. 1997;67(3):176-182.

20. Nicoletti AM, Silva LP, Hecktheuer LH, et al. Nutritional enrichment of macaroni with agribusiness by products. Alim Nutr. 2007;18(4):421-429.

21. Toloni MHA, Longo Silva G, Goulart RMM, et al. Introduction of processed and traditional foods to the diets of children attending public daycare centers in São Paulo, Brazil. Rev Nutr. 2011;24(1):61-70.

22. Bueno MB, Souza JMP, Souza SB, et al Risks associated with the weaning process in children born in a university hospital:a prospective cohort in the first year of life, São Paulo, 1998-1999. Cad Saúde Pública. 2003;19(5):1453-1460.

23. Jahns L, Siega-Riz AM, Popkin BM. The increasing prevalence of snacking among US children from 1977 to 1996. J Pediatr. 2001;138(4):493-498.

24. Birch LL. Development of food preferences. Annu Rev Nutr. 1999;19:4162.

25. Denardin CC, Boufleur N, Reckziegel P, et al. Influence rice or pasta intake on performance and metabolic response in rats. Alim Nutr. 2009;20(3):441-449.

26. Almeida ER, Carvalho AT, Nilson EAF, et al. Participatory evaluation of the National Program for Vitamin A Supplementation in a municipality in Northeast Brazil. Cad Saúde Pública. 2010;26(5):949-960.

27. Locard E, Mamelle N, Billette A, et al. Risk factors of obesity in a five year old population: parental versus environmental factors. Int $J$ Obes Relat Metab Disord. 1992;16(10):721-729.

28. Francis LA, Birch LL. Maternal weight status modulates the effects of restriction on daughters' eating and weight. Int J Obes. 2005;29(8):942949. 